\title{
Using Adult Learning Principles as a Framework for Learning ICT Skills Needed for Research Projects
}

\author{
Oduronke Temitope Eyitayo \\ University of Botswana, Gaborone, Botswana
}

\author{
eyitayoo@mopipi.ub.bw
}

\section{Executive Summary}

Students in higher institutions need to carry out research projects. The focus of this paper explores a model to help students learn ICT skills needed for research projects. Generally students go through the 'long and hard route' to learn and use ICT resources because they do not know how to do it. The paper explores the Adult Learning Theories as a model to develop the contents of an ICT information resource. Adult learning requires building on prior learning, using methods that treat learners with respect, and recognizing that people have different learning styles and have a variety of responsibilities and time commitments. The optimal role of the adult learner in the learning situation is that of a self-directed, self-motivated manager of personal learning who collaborates as an active participant in the learning process and who takes responsibility for learning. The modules developed were for Computer Operations, Internet, Microsoft Word ${ }^{\circ}$, Microsoft Excel ${ }^{\circledR}$ and PowerPoint ${ }^{\circledR}$. Forty-four students who volunteered evaluated the information resource. Based on the evaluation and comments and question from the students, the design of the information resource can be adjudged highly successful. All the functional requirements were met in the ICT information resource design. Students from three (3) out of the four (4) faculties rated their satisfaction of the functionality of the system at $100 \%$. The students highly regarded the perceived usefulness of the ICT information resource. Eight out of the 9 items related to perceived potential usefulness were rated at over $90 \%$, while only one item was rated at $88.6 \%$. Over $90 \%$ of the students agreed that the system has been designed with an understanding of their ICT skills need. In 9 out of the 10 items related to task technology fit, $85 \%$ of the students agreed to the Task Technology Fit. It is therefore expected that with the high level of their satisfaction with the perceived potential usefulness, and Task Technology Fit, the ICT information resource will be accepted, adopted and used by the students.

Keywords: Adult Learning, Self-Directed Learning, ICT Skills, Research Projects, Information Resource

Material published as part of this publication, either on-line or in print, is copyrighted by the Informing Science Institute. Permission to make digital or paper copy of part or all of these works for personal or classroom use is granted without fee provided that the copies are not made or distributed for profit or commercial advantage AND that copies 1) bear this notice in full and 2) give the full citation on the first page. It is permissible to abstract these works so long as credit is given. To copy in all other cases or to republish or to post on a server or to redistribute to lists requires specific permission and payment of a fee. Contact Publisher@InformingScience.org to request redistribution permission.

\section{Introduction}

Currently, many colleges and universities all over the world require students to demonstrate a prescribed level of computer proficiency. Many educational institutions offer introductory computer courses to assist students in meeting this requirement. The assumption is that these skills taught at the beginning of stu- 
dents' career will be able to carry them through the course or university life. However, research shows that this may be more of a perception than reality.

A study was carried out to analyze, design, and develop a prototype ICT skills information resource for final year undergraduate students to enable them to acquire ICT skills for their research work. There were several aspects to this study and they were based on different models. The focus of this paper is the instructional design aspect as well as the presentation of the results of the students' evaluation of the model used in the study. The modules developed were for Computer Operations, Internet, Microsoft Word $\AA$, Microsoft Excel ${ }^{\circledR}$ and PowerPoint ${ }^{\circledR}$. A detailed description of the information resource can be found in Eyitayo (2012).

Most theories of adult education place great value on prior learning and experience of adults, as well as relevance to the learner. Adult learning requires building on this prior learning, using methods that treat learners with respect, and recognizing that people have different learning styles and have a variety of responsibilities and time commitments. The optimal role of the adult learner in the learning situation is that of a self-directed, self-motivated manager of personal learning who collaborates as an active participant in the learning process and who takes responsibility for learning (Collins, 2004; Nesbit, Leach, \& Foley, 2004). Although this study is not about the adult learner, quite a number of the principles related to the adult learner are applicable to learning online. A major reason is that the online learner is mostly a self-directed learner. This is the principle behind the prototype design in this research.

This paper therefore discusses the methodology for the design, focusing on the use of adult learning principles and evaluating the developed resource. The three major research questions for the student evaluation review were:

1. What are the functional requirements for the ICT skills information resource?

2. What are the students' perceptions of the task-technology fit of the prototype system? and

3. What are the students' perceptions of the potential usefulness of the prototype system?

\section{Background to the Study}

The term 'Research Project' in this study refers to the undergraduate research done in the final year of study in the university. A typical research project requires word processing of a long document, some form of analysis, and a presentation. It sometimes also requires drawing charts, inserting pictures, copying data and graphics across applications, good internet skills, and managing citations. Though research itself is already a huge task to perform, students need adequate ICT skills to enable them handle all the activities linked to the research project.

ICT skills are a fundamental requirement for students and workers in the digital age. In schools, universities and in the work place, the question of how to utilize ICTs for learning purposes has become more and more important for anybody engaging in education and training as new technologies are spreading rapidly (Welle-Strand \& Thune, 2003, p. 1). Even if a learner is not doing what directly relates to computing, ICT skills are required to do most assignments and projects. In fact, virtually all university courses require basic computer knowledge. Similarly, more and more jobs are demanding that workers become increasingly familiar with using a wide range of computer applications.

In almost all departments at the University of Botswana, the independent research project is a common form of assessment required of final year students at undergraduate level. They are required to use their knowledge and skills to design experiments, analyze data, generate results, and ultimately present their research efforts and results in the form of a final research project report. The ICT skills required are normally expected to be acquired by students partly through two Gen- 
eral Education Courses taught in Year 1 to new students across two semesters. Each of the courses carries a weight of two credits. The University of Botswana (UB) uses the General Education Module approach to increase students' general education experience. However, looking at the requirements for ICT competencies, it is evident that this model will not meet the ICT competency requirements for a research project, thesis or dissertation. This is because the course is taught at first year and the skills taught do not cover the whole experience required in the university. Also when students are taught in the first year, they are likely to forget the skills before their final year (Eyitayo, 2011).

This researcher has been involved for several years in supporting final year undergraduate and graduate research students at UB and has noticed, in particular, a lack of basic ICT knowledge as students struggle with most computer applications. Most of the students spend a lot of time on simple ICT tasks, which indicates lack of adequate ICT skills. This lack of skills makes students to spend a lot of valuable time learning ICT skills simultaneously with doing their research projects. Sometimes, due to lack of skills, students use some of the ICT tools in most inefficient ways. A student for example can type the table of contents for a document separately and keep changing the pagination in the table each time corrections are made. This is a clear waste of time and a more efficient use of the application requires that this should be done with the use of the table of content feature in the application. Another common example is how to paginate a document based on different sections, which most students do not have the expertise to do. There have also been cases of students who have lost their entire project documents by accidentally saving blank documents over previously edited and saved versions of their documents. This is a clear case of not knowing how to make backups of their work. The examples above may be an indication that they do not have the necessary information to do things correctly. It is against this background that the researcher became concerned with the special ICT challenges facing undergraduate students and the need for a resource where they can find information to help them acquire the fundamental ICT skills required for their final year projects (Eyitayo, 2011).

\section{Students and ICT Skills: A Review of Literature}

Some institutions assume that students have acquired both computer knowledge (concepts) and computer skills before entering the University. Some are considering eliminating introductory computer courses with the expectation that students will demonstrate adequate computer knowledge through the proficiency examination (applications) in high school or through other personal experiences (Wallace \& Clariana, 2005, p. 1). However, research shows that the assumption that the students are skilled may be more of a perception than reality. This is confirmed in a statement by McEuen (2001, p. 16), "To say that our students, having grown up with digital media in their homes and in their schools, come to SU already equipped with skills and knowledge of information technology is a misconception." In a study carried out by McDonald (2004) on the computer literacy of students majoring in computer information systems (CIS) at Georgia State University in the USA, the results of the two-month pilot showed that $28.4 \%$ of graduate students failed to pass all six exams. For undergraduate students, the results were much worse with over $50 \%$ of CIS undergraduate majors not being successful.

A similar study of 140 incoming business freshmen in the School of Business at the College of New Jersey was carried out by Wallace and Clariana in 2005 to determine if students had adequate computer knowledge and skills to exempt them from an introductory computer fundamentals course. The results showed that the assumption that incoming freshman business students possess adequate knowledge of both computer concepts and computer literacy skills may not be accurate. The average scores of $58 \%$ on the concepts pre-test and $60 \%$ on the Microsoft Excel ${ }^{\circledR}$ pre-test respectively suggest that students do not possess the necessary skills to function in an undergraduate School of Business. In the study, $64 \%$ of the students failed or scored below $60 \%$ 
in one of the two tests indicating that only about one third of the freshman business students tested could be exempted from the course. They also noted that while some students may eventually pick up some computer skills during the course of their degree programme, they would most likely learn them imperfectly and not to the degree that is required.

Another study was carried out in 2007 at the Northern Arizona University because there was a debate on the appropriateness of the introduction to computer information systems course with the "increased" computer proficiency of incoming freshmen. A pre- post-test was conducted to provide information on the level of the computer conceptual knowledge for the college of business students. The results of the study showed that most students did not possess sufficient proficiency to be exempted from the course. Nineteen of the original 80 students (a little under 24\%) achieved a score equal to or greater than $60 \%$ in the pre-test. Even those students who achieved a passing score $(60 \%)$ after going through the course increased their computer conceptual knowledge by only $15 \%$ (VanLengen, 2009).

A more recent study by Karsten and Schmidt (2008) analyzed computer self-efficacy for two independent samples of students enrolled in an introduction to information systems course in 1996 and 2006 at the University of Northern Iowa and compared the results of the two years. They discovered that significant and substantial increases in computer experience and use did not translate into significantly higher levels of Computer Self- Efficacy (CSE) for the 2006 students. Their explanations for the results were that they suspect that students use computers much more frequently to communicate with others than to perform the kinds of information processing and problem-solving tasks required in introductory information systems courses. Social networking, e-mailing, text messaging, and instant messaging result in extensive computer use that requires the repetitive use of a limited range of skills, primarily entering text. Another possible reason they gave was that though students indicate that the number of courses that require computer use has significantly increased, the computer skills required in some of the courses may be narrow (e.g. word processing, presentations) or not consistently required, reinforced, or integrated across courses. Finally, they proposed that educators may sometimes fail to help make the connection between the skills and experiences students have and they may not actually realise the students have the skills expected. A similar study by Bond (2010) comparing undergraduate nurses' ability in 2004 and 2007 revealed increased basic skills, however, the ability to carry out more complex tasks did not improve over the years. Langley (2012) stated that although students may be labeled "digital natives", these students may not know how to employ technology-based tools strategically to optimize learning experiences in university settings.

Apart from freshmen, a few studies have been carried out on senior students in university environment. EDUCASE Center for Applied Research (ECAR) conducted a study of undergraduate students and their information technology skills in 2007 (Caruso \& Salaway, 2007). The survey used a questionnaire with a five-point scale rating of 1 (poor), 2 (fair), 3 (good), 4 (very good) and 5 (excellent) to ask students about their perception of their technology skills. The respondents who were seniors rated themselves as more highly skilled than those who were freshmen in online library skills, with $54.3 \%$ reporting "very good" or "excellent" skills compared to $40.3 \%$ of freshmen respondents. Respondents reported a similar pattern for spreadsheet skills. For other skills surveyed, which were course management system, presentation software, and computer maintenance, there was no meaningful skill difference between seniors and freshmen.

Another study by Kaminski, Switzer, and Gloeckner (2009) of university students' fluency with information technology measured students' proficiency on a four point scale of 1 (very proficient) to 4(never used). The results revealed that seniors were between "very proficient" and "somewhat proficient" in word processing (1.30), browser (1.32), and presentation software (1.81). They reported feeling "somewhat" and "marginally proficient" in graphics (2.70), while desktop publishing (3.15) and databases (3.15) were both reported close to "marginally proficient", web anima- 
tion (3.36), web development (3.37), programming (3.63), digital video (3.69), and digital audio (3.75) were all between "marginally proficient" and "never used". There was no significant difference in perceived ability for word processing, spreadsheet, graphics (Adobe, Photoshop, and Illustrator) and web development (Dreamweaver). All of the above studies were carried out in the developed world.

A study of the information and communication technology use by the world's children and youth carried out in 2008 by the International Telecommunications Union revealed that the level of ICT use is higher in the more developed economies. The reasons for this include better (and cheaper) access to ICT infrastructure and higher levels of discretionary spending per capita. If the gap between the developed and developing world is anything to reckon with, one might not expect a higher level of competency in universities in the less developed countries.

The lack of skills shown from the survey of Business and Computer Information Systems students in the various institutions of higher learning above could be an indication that some university students do not have the necessary skills for all the stages of their university existence. Usually Science and Business faculties are generally among the best skilled in ICT literacy than other faculties. This can also be confirmed by the results of University of Botswana (UB) students in the Computing and Information Skills Fundamentals courses over three years, students from these two faculties (Science and Business) always have had the best results (Department of Computer Science, 2010).

\section{Adult Learning Theory}

Instructional design is concerned with the promotion of processes that lead to successful learning regardless of the delivery medium being used, and it needs to be based upon appropriate learning theories (Smith \& Ragan, 1999). In this case principles from adult learning were found to be the most relevant for the design.

In the andragogy theory developed by Knowles (1980), four key principles of adult learning are identified. The principles are that (i) adults need to be involved in the planning and evaluation of their instruction; (ii) experiences (including mistakes) which adult learners bring to the training environment provide the basis for learning activities; (iii) adults are most interested in learning subjects that have immediate relevance to their job or personal life; and (iv) adult learning is problem-centred rather than content-oriented (DiLello \& Vaast, 2003).

The implications of this theory for design of the information resource are that the:

- tasks to be included are those identified and confirmed by final year students and their departments as required skills. This is based on the principle that adults need to be involved in the planning and evaluation of their instruction.

- design will concentrate on tasks students need to perform in their final year project. This is based on the principle that adult learning is problem-centered rather than contentoriented.

- content of instruction will concentrate mainly on final year project tasks, so that final year students can find the information they need easily. This is based on the principle that adults are most interested in learning subjects that have immediate relevance to their job or personal life

- students are told direct steps on how to perform a specific task at a time, without the normal long process of computer instructions. Students' previous experience will be tapped into, since they already know how to use computers and just need specific information on how to perform specific tasks. Instructions will therefore be broken into 
chunks where students can find answers to questions on "how do I perform a particular task in an application"? This is based on the principle that students' previous experiences provide a basis for learning. Also the role of the student in the learning situation is that of a self-directed, self-motivated manager of personal learning who takes responsibility for learning.

\section{Methodology/Design}

Based on the input from the analysis stage of the research, the subject contents of the information resource were finalized. The advanced skills that make research projects easy were identified. The information resource was designed based on identified competencies of students across the various departments. The subtopics and levels were also identified. The aim of the resource was not training but to give appropriate answers to specific questions that a student might have while working on their project. In the design, lessons learned from adult and self-directed learning as highlighted in the literature review were taken into consideration. The components taken into consideration were relevance/involvement, previous experiences and control over learning. This is illustrated in Table 1.

Table 1: Components of self-directed and adult learning

\begin{tabular}{|l|l|}
\hline Component & Description \\
\hline $\begin{array}{l}\text { Relevance/ } \\
\text { involvement }\end{array}$ & $\begin{array}{l}\text { Tasks included were those identified and confirmed through the survey by final } \\
\text { year students and their departments as the required skills. The design concen- } \\
\text { trated on ICT tasks students need to carry out their final year project. }\end{array}$ \\
\hline $\begin{array}{l}\text { Previous } \\
\text { experiences }\end{array}$ & $\begin{array}{l}\text { Students were directed on the steps required to perform specific tasks without } \\
\text { the normal long process of computer instructions. The instructions were broken } \\
\text { into chunks of how to perform specific tasks. }\end{array}$ \\
\hline $\begin{array}{l}\text { Control over } \\
\text { learning }\end{array}$ & $\begin{array}{l}\text { The components were divided into computer operations, e-mail, Internet, Micro- } \\
\text { soft Word } \AA \text {, Microsoft Excel } \AA \text { and Microsoft PowerPoint } \\
\text { topic, the major questions were identified and the appropriate answers provided. }\end{array}$ \\
\hline
\end{tabular}

The creation of an effective online environment requires thoughtful and appropriate design of the content materials (Siragusa \& Dixon, 2005). Eckersley (2003) observes that ICT literacy is most effectively developed through relevant and contextual use of ICT technologies. Concentrating on skills required in the final year projects puts the design in this context. Lee, Pliskin, and Kahn (1994) also state that computer literacy skills should be developed in a way that motivates and empowers students to use skills in the most effective manner possible so that students' prior experiences can be effectively acknowledged and built upon.

The prototype ICT information resource was designed based on identified competencies across the various departments. The aim of the resource is to give appropriate answers to specific questions students might have while working on their undergraduate research projects and expose them to the more advanced skills that make research work easier. The information needs analysis carried out helped to determine what the ICT information resource should contain. Confidence in accessing online courses was used to determine if eLearning would be a good medium to deliver the content. The results showed that students had a high level of confidence in accessing online courses, which confirms that it will be a good medium for the Information Resource. Email skills of the students were generally good and are not required for the research report and so it was excluded in the modules. With SPSS ${ }^{\circledR}$, training would be required because the students' skills were quite low to benefit from an information resource. Also, the results show that SPSS $₫$ is not a 
package required generally across all faculties, which is one of the conditions to include any component in the Information Resource. In total, there were five modules included in the Information Resource namely: computer operations; Internet; Microsoft Word $\AA$; Microsoft Excel ${ }^{\circledR}$

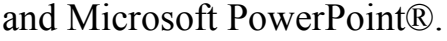

The Information Resource would allow students to check and find what they want and easily print or download what they find, with little or no distractions and minimal graphics. The structure of the information resource is a standard hierarchical arrangement with a capacity for non-sequential navigation following the Lynch and Horton (2002) hierarchical model and the digital content framework. In the design, lessons learned from adult and self-directed learning were taken into consideration.

During the data collection of the information needs analysis, students were asked to indicate if they would like some assistance with some ICT skills that will help with their research project. A total of eighty four (84) responded in the affirmative. E-mails were sent out, though some were returned due to wrong addresses. A total of forty-four (44) students evaluated the system in six (6) sessions. Each section included an introduction and demonstration before the students were asked to interact with the system. At the end there was an interactive session where students discussed freely before they were asked to fill the evaluation questionnaire. Each session lasted about two (2) hours. The evaluation sessions took place between the end of April and early May in 2010 .

The evaluation questionnaire comprised of four (4) sections. The first section was on demographic information of the respondents. The second section had nine (9) items that were based on the perceived potential usefulness and were adapted from Davis (1989) instruments. The third section had ten (10) items that were related to the task technology fit using a construct from Thompson, Higgins, and Howell's (1991) factors influencing the utilisation of Personal Computers (PCs). Task-technology fit used a construct task-technology fit measure from Thompson et al.'s (1991) factors influencing the utilisation of Personal Computers (PCs). The factors they used were based on the extent to which users agree with statements relating to potential application of PCs for related job efficiency, effectiveness, quality, and overall performance improvement, and measures, using 39 items on a 5 point likert scales ranging from strongly agree to strongly disagree. Of the 39 items, 19 were adapted for the evaluation. Ten items were related to the task technology fit while nine were based on the perceived potential usefulness and were adapted from Davis (1989) instruments. An additional question about the overall comments on the prototype was included at the last section of the questionnaire.

Data analysis involved the applications of standard statistical validity and reliability metrics. The research instrument validation was conducted using factor analysis and Cronbach alpha because some of the survey items and key constructs of the study have never been tested and used before. The collected data was analysed using percentage frequency analysis.

In summary, the relationship between the development methodology/instruments and the research questions are shown in Table 2. 
Table 2: Relationship between instruments and research questions for design aspect

\begin{tabular}{|l|l|l|}
\hline Research Question & Evaluation Model & Study Sample \\
\hline $\begin{array}{l}\text { What are the functional re- } \\
\text { quirements for the ICT skills } \\
\text { information resource? }\end{array}$ & $\begin{array}{l}\text { Thematic analysis of students' } \\
\text { use and evaluation }\end{array}$ & $\begin{array}{l}\text { 44 undergraduate students } \\
\text { from various departments }\end{array}$ \\
\hline $\begin{array}{l}\text { What are the students' per- } \\
\text { ceptions of the task- } \\
\text { technology fit of the proto- } \\
\text { type system? }\end{array}$ & Task-Technology Fit & $\begin{array}{l}44 \text { undergraduate students } \\
\text { from various departments }\end{array}$ \\
\hline $\begin{array}{l}\text { What are the students' per- } \\
\text { ceptions of the potential use- } \\
\text { fulness of the prototype sys- } \\
\text { tem? }\end{array}$ & $\begin{array}{l}\text { Perceived Potential Useful- } \\
\text { ness }\end{array}$ & $\begin{array}{l}44 \text { undergraduate students } \\
\text { from various departments }\end{array}$ \\
\hline
\end{tabular}

The evaluation scale was measured using 19 items. Reliability testing of these items using Cronbach Alpha indicated a strong reliability coefficient of $\alpha=.836$. Most of the items had high item to total correlation. There was no significant increase in reliability from dropping any of the scale items, and none of the items was dropped.

\section{Findings and Results}

The respondents for this survey were students in their final year in six faculties in the University of Botswana. The sample consists of sufficient numbers to meet the requirements for statistical significance as determined by statistical methods. The forty-four (44) students were from four (4) faculties: 8 (18.2\%) from Business, 17 (38.6\%) from Humanities, 4 (9.1\%) from Science, while $15(34.1 \%)$ were from Social Sciences. The distributions of the students who evaluated the system revealed that 17 (38.6\%), of them were female while $25(56.8 \%)$ were male. Of the 44 students, $2(4.5 \%)$ were below 20 years, $30(68.2 \%)$ were between 20 and 25, $9(20.5 \%)$ were between 25 and 30 years, while $3(4.6 \%)$ were above 30 years.

It can be seen from Table 3 that students highly regarded the perceived usefulness of the ICT information resource. Over $88 \%$ of the students' responded with either strongly agree (5) or agree (4) in all the 9 items related to the perceived usefulness.

Table 3: Percentage summary of perceived potential usefulness

\begin{tabular}{|l|l|l|l|l|l|l|l|}
\hline & $\begin{array}{l}\mathbf{1} \\
\text { Strongly } \\
\text { Disagree }\end{array}$ & $\mathbf{2}$ & $\mathbf{3}$ & $\begin{array}{l}\text { Sum } \\
\mathbf{( 1 - 3 )}\end{array}$ & $\mathbf{4}$ & $\begin{array}{l}\mathbf{5} \\
\text { Strongly } \\
\text { Agree }\end{array}$ & $\begin{array}{l}\text { Sum } \\
\mathbf{( 4 - 5 )}\end{array}$ \\
\hline $\begin{array}{l}\text { Using the system will give me } \\
\text { greater control over the ICT skills } \\
\text { I need for my research project }\end{array}$ & 0 & 2.3 & 0 & 2.3 & 27.3 & 70.5 & 97.8 \\
\hline $\begin{array}{l}\text { Use of the system will signifi- } \\
\text { cantly increase the quality of my } \\
\text { report }\end{array}$ & 0 & 0 & 2.3 & 2.3 & 20.5 & 77.3 & 97.8 \\
\hline $\begin{array}{l}\text { Use of the system will increase } \\
\text { the effectiveness of ICT tasks for } \\
\text { my research project }\end{array}$ & 0 & 0 & 0 & 0 & 43.2 & 54.5 & 97.7 \\
\hline
\end{tabular}




\begin{tabular}{|l|l|l|l|l|l|l|l|}
\hline & $\begin{array}{l}\mathbf{1} \\
\text { Strongly } \\
\text { Disagree }\end{array}$ & $\mathbf{2}$ & $\mathbf{3}$ & $\begin{array}{l}\text { Sum } \\
\mathbf{( 1 - 3 )}\end{array}$ & $\mathbf{4}$ & $\begin{array}{l}\mathbf{5} \\
\text { Strongly } \\
\text { Agree }\end{array}$ & $\begin{array}{l}\text { Sum } \\
\mathbf{( 4 - 5 )}\end{array}$ \\
\hline $\begin{array}{l}\text { Using the system will make it } \\
\text { easier for me to write my report }\end{array}$ & 2.3 & 0 & 0 & 2.3 & 34.1 & 63.6 & 97.7 \\
\hline $\begin{array}{l}\text { I will find the system useful in } \\
\text { my work }\end{array}$ & 0 & 2.3 & 2.3 & 4.6 & 22.7 & 72.7 & 95.4 \\
\hline $\begin{array}{l}\text { Use of the system will increase } \\
\text { the quality of my research for the } \\
\text { same amount of effort }\end{array}$ & 0 & 0 & 6.8 & 6.8 & 34.1 & 59.1 & 93.2 \\
\hline $\begin{array}{l}\text { The system will enable me to } \\
\text { complete my research project } \\
\text { more quickly }\end{array}$ & 0 & 2.3 & 6.8 & 9.1 & 29.5 & 61.4 & 90.9 \\
\hline $\begin{array}{l}\text { Using the system will allow me } \\
\text { to accomplish more work than } \\
\text { would otherwise be possible }\end{array}$ & 0 & 2.3 & 4.5 & 6.8 & 31.8 & 59.1 & 90.9 \\
\hline $\begin{array}{l}\text { The system will support critical } \\
\text { aspects of my research project } \\
\text { task }\end{array}$ & 2.3 & 2.3 & 6.8 & 11.4 & 38.6 & 50 & 88.6 \\
\hline
\end{tabular}

However, when grouped into faculties, the perceived usefulness was rated at $100 \%$ by all except for Humanities where it ranged between 70 and 94\%, as shown in Table 4. The result supports the findings at the analysis stage that showed that Humanities students seem to have better ICT skills for research than other faculties.

Table 4: Percentage summary of perceived potential usefulness by faculty

\begin{tabular}{|l|l|l|l|l|}
\hline \multicolumn{4}{|l|}{ Agree/Strongly Agree } \\
\hline & Business & $\begin{array}{l}\text { Human- } \\
\text { ities }\end{array}$ & Science & $\begin{array}{l}\text { Social } \\
\text { Sciences }\end{array}$ \\
\hline $\begin{array}{l}\text { Using the system will give me greater control } \\
\text { over the ICT skills I need for my research project }\end{array}$ & $100.0 \%$ & $94.1 \%$ & $100.0 \%$ & $100.0 \%$ \\
\hline $\begin{array}{l}\text { The system will enable me to complete my re- } \\
\text { search project more quickly }\end{array}$ & $100.0 \%$ & $78.5 \%$ & $100.0 \%$ & $100.0 \%$ \\
\hline $\begin{array}{l}\text { The system will support critical aspects of my } \\
\text { research project task }\end{array}$ & $100.0 \%$ & $70.6 \%$ & $100.0 \%$ & $100.0 \%$ \\
\hline $\begin{array}{l}\text { Use of the system will increase the effectiveness } \\
\text { of ICT tasks for my research project }\end{array}$ & $100.0 \%$ & $100.0 \%$ & $100.0 \%$ & $100.0 \%$ \\
\hline $\begin{array}{l}\text { Using the system will allow me to accomplish } \\
\text { more work than would otherwise be possible }\end{array}$ & $100.0 \%$ & $82.4 \%$ & $100.0 \%$ & $100.0 \%$ \\
\hline $\begin{array}{l}\text { Using the system will make it easier for me to } \\
\text { write my report }\end{array}$ & $100.0 \%$ & $94.1 \%$ & $100.0 \%$ & $100.0 \%$ \\
\hline $\begin{array}{l}\text { Use of the system will significantly increase the } \\
\text { quality of my report }\end{array}$ & $100.0 \%$ & $94.1 \%$ & $100.0 \%$ & $100.0 \%$ \\
\hline $\begin{array}{l}\text { Use of the system will increase the quality of my } \\
\text { research for the same amount of effort }\end{array}$ & $100.0 \%$ & $88.3 \%$ & $100.0 \%$ & $100.0 \%$ \\
\hline I will find the system useful in my work & $100.0 \%$ & $88.2 \%$ & $100.0 \%$ & $100.0 \%$ \\
\hline
\end{tabular}


As shown in Table 5, over $86 \%$ of the students responded with either "agree" or "strongly agree" in 9 out of the 10 items related to task technology fit. The only exception is on the item 'The system is not missing critical information that will be useful in the task of my research project', for which $77.3 \%$ "agreed" or "strongly agreed" that it met their needs. Overall, students felt that the ICT information resource fitted into their task and they can easily follow the steps.

Table 5: Percentage summary of evaluation of Task Technology Fit

\begin{tabular}{|l|l|l|l|l|l|l|l|}
\hline & $\begin{array}{l}\text { Strongly } \\
\text { Disagree }\end{array}$ & $\mathbf{2}$ & $\mathbf{3}$ & Sum(1-3) & $\mathbf{4}$ & $\begin{array}{l}\text { Strongly } \\
\text { Agree }\end{array}$ & $\begin{array}{l}\text { Sum } \\
\text { (4-5) }\end{array}$ \\
\hline $\begin{array}{l}\text { The section headings clearly in- } \\
\text { dicate what information is con- } \\
\text { tained within the section }\end{array}$ & 0 & 0 & 2.3 & 2.3 & 40.9 & 56.8 & 97.7 \\
\hline $\begin{array}{l}\text { It is easy to determine what in- } \\
\text { formation is available in the re- } \\
\text { source }\end{array}$ & 0 & 0 & 6.8 & 6.8 & 43.2 & 50 & 93.2 \\
\hline $\begin{array}{l}\text { Data from different sources are } \\
\text { combined appropriately in the } \\
\text { information resource }\end{array}$ & 0 & 0 & 6.8 & 6.8 & 40.9 & 52.3 & 93.2 \\
\hline $\begin{array}{l}\text { I can count on the system to be } \\
\text { consistent }\end{array}$ & 0 & 0 & 6.8 & 6.8 & 40.9 & 50 & 90.9 \\
\hline $\begin{array}{l}\text { The system has been designed } \\
\text { with an understanding of my ICT } \\
\text { skills need }\end{array}$ & 0 & 0 & 6.8 & 6.8 & 34.1 & 56.8 & 90.9 \\
\hline $\begin{array}{l}\text { I am satisfied with the functional- } \\
\text { ity of the system }\end{array}$ & 0 & 0 & 6.8 & 6.8 & 31.8 & 59.1 & 90.9 \\
\hline $\begin{array}{l}\text { The system delivers solution to } \\
\text { support my research project ICT } \\
\text { tasks. }\end{array}$ & 0 & 0 & 6.8 & 6.8 & 34.1 & 56.8 & 90.9 \\
\hline $\begin{array}{l}\text { The steps to follow in any task } \\
\text { are clear }\end{array}$ & 0 & 0 & 9.1 & 9.1 & 52.3 & 36.6 & 88.9 \\
\hline $\begin{array}{l}\text { It is easy for me to understand } \\
\text { what each question in the infor- } \\
\text { mation resource is intended for }\end{array}$ & 0 & 0 & 11.4 & 11.4 & 50 & 36.4 & 86.4 \\
\hline $\begin{array}{l}\text { The system is not missing critical } \\
\text { information that will be useful in } \\
\text { the task of my research project }\end{array}$ & 2.3 & 0 & 20.5 & 22.8 & 40.9 & 36.4 & 77.3 \\
\hline
\end{tabular}

When this was grouped into faculties (see Table 6), the task technology fit was more suited towards Science students, closely followed by Social sciences and then Humanities. Business students rated some items in the task-technology-fit quite low. From the qualitative response to some of the questions on the questionnaires, more business students require the use of SPSS $®$ and other specific applications such as ACCPAC for their research, and this might be reason for their rating. 
Table 6: Percentage summary of evaluation of Task Technology Fit by Faculty

\begin{tabular}{|l|l|l|l|l|}
\hline & Agree/Strongly Agree & \multicolumn{2}{l|}{} \\
\hline & Business & Humanities & Science & $\begin{array}{l}\text { Social } \\
\text { Sciences }\end{array}$ \\
\hline $\begin{array}{l}\text { It is easy for me to understand what each } \\
\text { question in the information resource is in- } \\
\text { tended for }\end{array}$ & $62.5 \%$ & $100.0 \%$ & $100.0 \%$ & $86.6 \%$ \\
\hline The steps to follow in any task are clear & $87.5 \%$ & $88.8 \%$ & $100.0 \%$ & $100.0 \%$ \\
\hline I can count on the system to be consistent & $87.5 \%$ & $82.4 \%$ & $100.0 \%$ & $100.0 \%$ \\
\hline $\begin{array}{l}\text { The system has been designed with an under- } \\
\text { standing of my ICT skills need }\end{array}$ & $100.0 \%$ & $76.5 \%$ & $100.0 \%$ & $100.0 \%$ \\
\hline $\begin{array}{l}\text { I am satisfied with the functionality of the } \\
\text { system }\end{array}$ & $100.0 \%$ & $82.3 \%$ & $100.0 \%$ & $93.4 \%$ \\
\hline $\begin{array}{l}\text { The system delivers solution to support my } \\
\text { research project ICT tasks. }\end{array}$ & $100.0 \%$ & $82.4 \%$ & $100.0 \%$ & $93.4 \%$ \\
\hline $\begin{array}{l}\text { It is easy to determine what information is } \\
\text { available in the resource }\end{array}$ & $87.5 \%$ & $94.1 \%$ & $100.0 \%$ & $93.4 \%$ \\
\hline $\begin{array}{l}\text { The system is not missing critical information } \\
\text { that will be useful in the task of my research } \\
\text { project }\end{array}$ & $62.5 \%$ & $76.5 \%$ & $75.0 \%$ & $86.6 \%$ \\
\hline $\begin{array}{l}\text { The section headings clearly indicate what } \\
\text { information is contained within the section }\end{array}$ & $100.0 \%$ & $100.0 \%$ & $100.0 \%$ & $93.4 \%$ \\
\hline $\begin{array}{l}\text { Data from different sources are combined } \\
\text { appropriately in the information resource }\end{array}$ & $87.5 \%$ & $94.1 \%$ & $100.0 \%$ & $93.4 \%$ \\
\hline
\end{tabular}

The students' narrative comments supported ease of use and usefulness of the resource. Other comments suggested adding it as part of the curriculum and introducing students to it earlier. There was also a suggestion on including SPSS ${ }^{\circledR}$ in the resource. Details of the students' comments are reported below. The $\mathrm{R}$ and the number is just an assigned number to the respondent.

Comments from Students from Faculty of Business:

R4: "This session has been very helpful; however, I feel that access to our Moodle accounts should be extended beyond a semester. If this is not possible then perhaps a small booklet could be useful."

R8: "This is an excellent online module and it has been extremely helpful to me. I wish it had come earlier than in my final year semester. It is simple and easy to understand. I wish however that there were resources about SPSS $\AA$ as that would have been even more useful."

R12: "The system is very good."

R 39: "The Information Resource is quite good since it's something we would be using anywhere we find ourselves so the demo should be done at least twice a semester in order to be of good help to the people who are writing projects and stuffs."

R41: "The information I got from the short demo was useful and it shed light on some things I did not know was possible. I think the ICT skills should be provided to all the 3 rd year who will be doing a research project." 
R42: "It is easy to understand and very useful for research projects and reports. It saves time and helps in avoiding mistakes."

Comments from Students from Faculty of Humanities:

R9: "The information resource is useful as it gives a quick guide on what to do."

R10: "I wish the system was introduced before I started the research. It has critical information for the research project."

R13: "It should be provided to students in their first year to UB so that they know this information when doing their assignment."

R15: "The lessons made it easier to learn the skills and use when appropriate. It is very important to give completing students a semester lesson on ICT skills."

R16: "I recommend that this lesson should be provided to students every year so that we get to know almost everything about ICT skills. It is very good and I am so happy to be part of it."

R17: "The system is very good and of course very convenient. This is something we could have been taught at first year level as a course and not now!"

R18: "The ICT skills that I've learnt are very useful and it would be important if all students could get access to this system as it would make their work a lot easier."

R19: "The system is very good, quick and convenient. It just came at the wrong time. Next time it will be important if it is done at first year level."

R20: "This type of knowledge would be useful to all students in the university; I therefore suggest that the ICT skills be taught at first year level."

R23: "It was excellent. I wish it was taught at first year because it is omitted in our General Education courses."

R28: "This lesson showed more easier ways of doing things. I have been doing them the harder way. Thanks for the lesson."

R37: "This is very good and can save valuable time."

Comments from Students from Faculty of Science:

R3: "The system is good especially to the students who are carrying out their final year projects. I believe the training should be extended to be made compulsory to all university students or offered as a General Education Course."

R38: "The information resource is an excellent source, it saves time and makes work much easier. It should be made available to the student community as soon as possible."

R40: "Very useful, efficient, can help many students. I think students should be made alert or try as much as possible to access it. It is very important in whatever field. And it's very effective for project usage."

R44: "The demonstration is relevant and personally I would highly recommend it to every student. If possible it should even be incorporated into computer skills course because it would greatly benefit students across all faculties. Keep up the good work." 
Comments from Students from Faculty of Social Sciences:

R1: "The information resource is well articulated and very easy to understand."

R2: "I think the system is a good initiative which should be introduced to students as early as year one. It would be a useful resource for our assignments and projects. Some of us struggled with our projects while there was an easy way out."

R5: "The system is good and wish to sit down and learn more about it when I am alone. My PowerPoint ${ }^{\circledR}$ presentation will be better made and presented. As for my research report, I will be able to do it in less time than before. Thanks!!!"

R14: "I wish the course was introduced earlier especially at first year level. It is very useful in research proposal writing and final research projects."

R21: "Brilliant!!! It's a time saver."

R22: "The whole exercise was really innovative and I wish that an on-going education for all students in the university will encompass the skills we learnt today. I really appreciate effort to input these excellent, priceless skills into my life as I am graduating from the University of Botswana."

Some results from the evaluation of the prototype design are as follows:

i. Over $90 \%$ of the students were satisfied with the functionality of the system.

ii. In terms of control, $98 \%$ of the students agreed that using the system will accord them greater control over the ICT skills needed for their research project.

iii. Over $90 \%$ of the students agreed that the system will enable them to complete their research project more quickly.

iv. On the issue of support, $89 \%$ of the students agreed that the system will support critical aspects of their research project task.

v. Ninety-eight of the students agreed that the use of the system will increase the effectiveness of ICT tasks for their research project.

vi. Ninety-one percent of the students agreed that using the system would allow them to accomplish more work than will otherwise be possible, using the system will make it easier for them to write their report.

vii. In terms of its usefulness, $98 \%$ of the students agreed that use of the system will significantly increase the quality of their report and that they will find the system useful in their work.

viii. Ninety-one percent of the students agreed that the system has been designed with an understanding of their ICT skills need.

ix. Overall, students felt that the ICT information resource fitted into their task and that they could easily follow the steps.

\section{Discussions and Conclusions}

The purpose of the prototype development aspect of this research was to design and develop an ICT information resource for final year research projects. This section addresses the research questions in the design and development part of the research. The design, developmental aspect sought to examine the functional requirements for the ICT skills information resource, students' 
perceptions of the task-technology fit of the prototype system as well as students' perceptions of the potential usefulness of the prototype system.

Like any information system, the success of learning object technology also depends on user satisfaction and acceptance (Lau \& Woods, 2008). This section discusses the evaluation based on the three research questions.

\section{RQ1: What are the functional requirements for the ICT skills information resource?}

It is important that the functionality of learning objects and any interactions to be used should be carefully designed as interactivity is influenced by the degree of learner control as well as the availability of the functional features that encourage users to actively learn (Lau \& Woods, 2008; Robertson, 1998; Stoney \& Wild, 1998). The thematic analysis of students' use, evaluation and question and answer session on the ICT resource revealed three functional requirements:

- The system shall provide appropriate questions and answers that will help in areas where ICT skills are needed for research

- The system shall provide appropriate view for the user to read the answers to the questions

- The user shall be able to search the contents of the modules and select appropriate ones that answer their questions.

All these requirements were met in the ICT information resource design. Students from three (3) out of the four (4) faculties rated their satisfaction of the functionality of the system at $100 \%$. Only students from the faculty of Humanities rated their satisfaction at $82.3 \%$.

\section{RQ2: What are the students' perceptions of the potential usefulness of the prototype sys- tem?}

The students highly regarded the perceived usefulness of the ICT information resource. Eight out of the nine items related to perceived potential usefulness were rated at over $90 \%$, while only one item was rated at $88.6 \%$. Except for students' from the faculty of Humanities, all the students agreed that using the system will give them greater control over the ICT skills they need for their research project. They also agreed that the system will enable them to complete their research project more quickly and will support critical aspects of their research project task. Furthermore, they agreed that using the system will increase the effectiveness of ICT tasks for their research project. It will enable them to accomplish more work than would otherwise be possible, and the system will make it easier for them to write their report. They also all agreed that the use of the system will significantly increase the quality of their report and that they would find the system useful in their work.

According to Stokes (2001) a high level of user satisfaction reflects the users' willingness to accept and continue using technology. This is also confirmed by Lau and Woods (2008) who predict that behavioural intention to use is jointly determined by a person's attitude toward using the system and its perceived usefulness. Therefore, behavioural influence determines actual use. It is expected that with the high level of their satisfaction with the perceived potential usefulness, students will both accept and use the ICT information resource.

\section{RQ3: What are the students perceptions of the task-technology fit of the prototype system?}

Over $90 \%$ of the students agreed that the system has been designed with an understanding of their ICT skills need. In 9 out of the 10 items related to task technology fit, $85 \%$ of the students agreed to the Task Technology Fit. From the discussion with the students and their narrative comments, it can be inferred that some students from the Faculty of Business wanted SPSS $₫$ skills included, which was not included in the ICT information resource because the need was not general to all 
the faculties. One of the goals set out at the beginning of the research was that the contents of the resource should be useful to the six faculties. However, overall, students felt that the ICT information resource fitted into their task and they could easily follow the steps. Lau and Woods (2008) in their model proposed that educators and instructional designers of learning objects should ensure compatibility between learning objects and users' need in order to enhance the adoption of learning objects' for individual learning. It is therefore expected that with the high level of fit between the task and technology, the ICT information resource will be adopted for use by the students.

Based on the evaluation and comments from the students, the design of the information resource can be adjudged highly successful. The Information Resource with the use of adult learning principles has contributed to this success. The perceived potential usefulness and task technology fit were quite high. Over $90 \%$ of the students in the evaluation team agreed that the system has been designed with an understanding of the ICT skills they need, they were satisfied with the functionality of the system and will give them greater control over the ICT skills they need for their research project, and they felt the system will enable them to complete their research project more quickly and increase the quality of their report. It is therefore expected that with the high level of their satisfaction with the perceived potential usefulness, and Task Technology Fit, the ICT information resource will be accepted, adopted, and used by the students.

The development of the prototype, which involved the fusion of several current resources and the use of adult learning principles, has provided relevant information that will help the students to do their research with ease. The ICT skills will empower the students to handle more complex tasks and motivate them to use more advanced features of the packages. The information resource will help students to acquire the desired ICT skills as well as develop self-directed lifelong learning skills. The resource will also aid making decisions about the appropriate level of computer training that students require. These ICT skills will empower the students to handle more complex tasks and motivate them to use more advanced features of the packages. The developed resource is expected to lead to the reduction of the time spent in producing reports and ultimately result in the production of research of better quality. The same prototype could serve as a resource for academic departments as well as meet the ICT needs of various faculties, graduate students and academic staff in the pursuit of their research.

The study was confined to determining general ICT skills required in final year research project and providing a prototype resource to meet such needs. It did not cater for ICT skills required for other purposes. Information technology changes rapidly and may have an effect on the results of the study since the research project took about three years. However, in the process of the research, changes were catered for in order to minimize the effect of the rapid change.

\section{References}

Bond, C. S. (2010). Surfing or still drowning? Student nurses' Internet skills. Nurse Education Today, $30(15), 485-488$.

Caruso, J. B., \& Salaway, G. (2007, September). The ECAR Study of undergraduate students and information technology, 2007 (Key Findings). EDUCASE, 1-15.

Collins, J. (2004). Education techniques for lifelong learning: principles of adult learning. Radiographics, $24,1483-1489$.

Davis, F. D. (1989). Perceived usefulness, perceived ease of use, and user acceptance of information technology . MIS Quarterly, 13(3), 319-340.

Department of Computer Science. (2010). Handbook 2009/2010. Faculty of Science, University of Botswana. 
DiLello, A., \& Vaast, K. (2003). Using adult learning theory. Retrieved 26 January 2007 from http://clodiva.wordpress.com/2006/10/20/using-adult-learning-theory

Eckersley, C. (2003). Self-paced, e-learning - What value to universities. Retrieved 26 January 2007 from http://surveys.canterbury.ac.nz/herdsa03/pdfsnon/N1048.pdf

Eyitayo, O. T. (2011). Design and development of a prototype ICT skills information resource for University of Botswana final year undergraduate students. Unpublished doctoral dissertation, University of Botswana, Gaborone.

Eyitayo, O. T. (2012). Design and development of a prototype ICT skills information resource for research projects using TPTF model. International Journal of Information and Communication Technology Research, 2(8). Retrieved from http://esjournals.org/journaloftechnology/archive/vol2no8/vol2no8_5.pdf

International Telecommunications Union. (2008). Use of information and communication technology by the world's children and youth: A statistical compilation June 2008. Retrieved 4 May, 2008 from http://www.itu.int/ITU-D/ict/material/Youth_2008.pdf

Kaminski, K., Switzer, J., \& Gloeckner, G. (2009). Workforce readiness: A study of university students' fluency with information technology. Computers \& Education, 53, 228-233.

Karsten, R., \& Schmidt. (2008). Business student computer self-efficacy: Ten years later. Journal of Information Systems Education, 19(4), 445-453.

Knowles, M. S. (1980). The modern practice of adult education: From pedagogy to andragogy. New York: Cambridge Books.

Langley, D. (2012). IT in academic learning: Views from student survey projects. Proceedings of Informing Science \& IT Education Conference (pp. 129-150). Informing Science Institute.

Lau, S., \& Woods, P. C. (2008). An empirical study on student's acceptance of learning objects. Journal of Applied Sciences, 8(22), 4079-4085.

Lee, D., Pliskin, N., \& Kahn, B. (1994). The relationship between performance in a computer literacy course and student's prior achievement and knowledge. Journal of Educational Computing Research, $10(1), 25-40$.

Lynch, P. J., \& Horton, S. (2002). Web style guide: Basic design principles for creating web sites (2nd ed.). New Haven, CT: Yale University Press.

McDonald, D. S. (2004). Computer literacy skills for computer information systems majors: A case study. Journal of Information Systems Education, 15(1). Retrieved from http://jise.org/Volume15/151/Pdf/19-abs.pdf

McEuen, S. F. (2001). How fluent with Information Technology are our students? A survey of students from Southwestern University explored how FIT they see themselves. EDUCASE Quarterly (4).

Nesbit, T., Leach, L., \& Foley, G. (2004). Teaching Adults. In G. Foley (Ed.), Dimensions of adult learning: Adult education and training in a global era. New South Wales, Australia: Allen \& Unwin.

Robertson, J. (1998). Paradise lost: Children multimedia and the myth of interactivity. Journal of Computer Assisted Learning, 14, 31-39.

Siragusa, L., \& Dixon, K. C. (2006). A theoretical framework for research and development into sound online learning in higher education. In P. L. Jeffery (Ed.), AARE Conference - 2005. Retrieved 1 November 2007 from http://www.aare.edu.au/05pap/sir05363.pdf

Smith, P. L., \& Ragan, T. J. (1999). Instructional Design (2nd ed.). New York: John Wiley \& Sons.

Stokes, S. P. (2001). Satisfaction of college students with the digital learning environment: Do learners' temperaments make a difference? Internet Higher Education, 4(1), 31-44.

Stoney, S., \& Wild. (1998). Motivation and interface design: maximizing learning opportunities. Journal of Computer Assisted Learning, 14, 40-50. 
Thompson, R. L., Higgins, C. A., \& Howell, J. M. (1991). Personal computing: Toward a conceptual model of utilization. MIS Quarterly, 15(1), 125-143.

VanLengen, C. (2009). Computer literacy proficiency testing. Information Systems Education Journal, 7(46). Retrieved from http://isedj.org/7/46/ISEDJ.7\%2846\%29.VanLengen.pdf (A preliminary version appears in The Proceedings of ISECON 2007)

Wallace, P., \& Clarina, R. (2005). Perception versus reality--Determining business students computer literacy skills and need for instruction in information concepts and technology. Journal of Information Technology Education, 4, 141-151. Retrieved from http://www.jite.org/documents/Vol4/v4p141151Wallace59.pdf

Welle-Strand, A., \& Thune, T. (2003). E-Learning policies, practices and challenges in two Norwegian organizations. Evaluation and program planning, 26(2), 185-192.

\section{Biography}

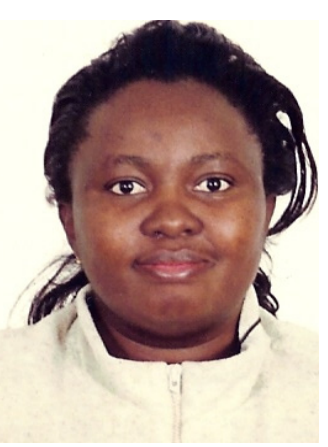

Oduronke T. Eyitayo, $\mathbf{P h D}$ is currently a Senior Lecturer in the Department of Computer Science, University of Botswana. She has a B.Sc in Computer Science, Masters in Information Science and a PhD in Information Studies. She is interested in making ICT resources easy and simple to use for the end-users. She has been involved in teaching, training, writing materials and developing resources that enhance enduser experiences on the use of computing devices. She has published articles addressing different issues in Information Technology and presented papers at several conferences. 